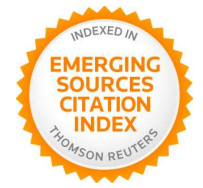

\title{
Developments in ESP: from register analysis to a genre-based and CLIL-based approach
}

\author{
Isabel Negro Alousque ${ }^{1}$ \\ Universidad Complutense de Madrid
}

\begin{abstract}
English for Specific Purposes (ESP) has developed in the last five decades in response to learners' communicative needs in specific scientific fields and professional settings. Since its emergence in the 1960s the number of publications on ESP has spread both on a theoretical and practical basis, although the bulk of the research has focused on ESP pedagogy, syllabus, course design and classroom-based practice. The present paper aims to trace the evolution of ESP from the beginning of the movement in the mid-1960s to the present day. We will see that the major ESP developments are in consonance with developments in the fields of theoretical and applied linguistics. In this light, four phases can be distinguished: (1) mid-1960 - early 1970s; (2) mid-1970s - mid-1980s; (3) mid-1980s - 1990s; (4) 2000-present. Another outstanding development in ESP is related to the predominance of the different ESP strands. While English for Science and Technology was dominant in early ESP, today English for Academic Purposes and Business English are the largest areas of activity.
\end{abstract}

Keywords: ESP; needs analysis; register; genre; CLIL.

\section{Resumen}

El inglés para fines específicos se ha desarrollado en las últimas cinco décadas en respuesta a las necesidades comunicativas de los alumnos en ámbitos científicos y entornos profesionales concretos. Desde su aparición en los años 60 se ha incrementado el número de publicaciones sobre aspectos teóricos y prácticos, aunque la mayoría de las investigaciones se han centrado en la pedagogía, la programación, el diseño de cursos y la práctica en el aula. Este artículo pretende describir la evolución del inglés para fines específicos desde sus comienzos a mediados de los años 60 hasta la actualidad. Los mayores cambios son paralelos a la evolución de la lingüística teórica y aplicada. En este sentido, se distinguen cuatro etapas: (1) mediados años 60 - comienzos años 70; (2) mediados años 70

Corresponding author - Universidad Complutense de Madrid, Departamento de Filología Inglesa I, Madrid (Spain). Email: inegro@ccee.ucm.es 
- mediados años 80; (3) mediados años 80 - años 90; (4) desde el año 2000 hasta el presente. Otro cambio significativo en el inglés para fines específicos atañe al predominio de las distintas ramas. Si el inglés para la ciencia y la tecnología dominó en los primeros años, hoy el inglés para fines académicos y el inglés empresarial son los ámbitos más amplios.

Palabras clave: inglés para fines específicos; análisis de necesidades; registro; género; aprendizaje integrado de contenidos.

\section{Introduction}

In the last five decades there has been a growing demand for the knowledge of English to communicate in academic and professional contexts, which has led to the development of English for Specific Purposes (hence ESP), sometimes referred to as English for Professional and Academic Purposes (hence EPAP) (Ruiz et al., 2010). The burgeoning ESP literature tackles theoretical issues, the pedagogical standpoint of ESP and ESP applications in numerous publications including books, papers, journals ${ }^{2}$ and teaching materials. The main research line is ESP course design (syllabus design, methodology, materials, evaluation and roles of the ESP teacher).

The present contribution follows a descriptive approach that provides a comprehensive view of ESP by looking at the evolution of the movement since its beginning in the mid-1960s up to date. The paper explains the changes experienced by ESP throughout its history. Such changes have been determined by shifting approaches to language and language teaching. In the first stage (mid-1960s to early 1970s), register was the basis of research in ESP, especially in scientific and technical English. The linguistic features and functions of scientific English were identified and taught. From the mid-1970s to the mid-1980s ESP practice was influenced by rhetorical analysis, needs analysis and the skills and strategies approach. Genre analysis, especially under the influence of Swales' and Bhatia's work, has assumed a central position in ESP in the third and fourth stages of ESP.

The major changes concern ESP teaching. Thus, while in the 1990s a learningcentered approach was dominant, since 2000 many ESP university courses have been based on the Content Language Integrated Learning approach

2 English for Specific Purposes, The ESP-ecialist, Journal of English for Academic Purposes, Ibérica, and journals that feature articles on ESP: Applied Linguistics, The ELT Journal, TESOL Quarterly or Language Teaching, to mention but a few. 
(CLIL), a dual-focused approach in which an additional language, usually English, is used for the learning and teaching of subject content and language.

The structure of the paper is as follows. The first section provides a general characterization of the ESP phenomenon and the ESP branches. This is followed by a historical overview of ESP. We explain the stages in the development of the ESP movement since its emergence to the present and we assess the contributions of the different approaches to ESP. In the fourth section we briefly comment on what the future may hold for ESP. We finally present some concluding remarks.

\section{A general characterization of ESP}

The ESP phenomenon is difficult to define since the views of ESP differ greatly. Some specialists see ESP as a teaching process. Thus Hutchinson and Waters $(1987$, p. 21) see ESP as "an approach to language teaching which aims to meet the needs of particular learners." Similarly, Dudley-Evans and St John (1998, p. 19) define ESP as "a materials- and teaching-led movement." Other specialists see ESP as a learning process. Thus in Wilkinson's view (2008, p. 61) ESP is "a training process which is directed to learning to produce a known outcome." Finally, ESP is sometimes regarded as a discourse type. In this light, Ruiz Garrido (Ruiz et al. 2010, p.1) remarks that ESP is "the special discourse used in special settings by people sharing common purposes."

ESP can be described in terms of core and non-core features in the light of the characterizations proposed by ESP researchers ${ }^{3}$, as shown in figure 1:

Robinson's (1991) definition of ESP is based on two defining criteria - ESP is goal-directed and develops from a needs analysis - and two characteristics: ESP courses are taught to adult students and are generally short. By contrast, Strevens (1998), Dudley-Evans \& St John (1998) and Anthony (1997) define ESP in terms of absolute characteristics and variable characteristics. The most relevant absolute characteristics are: (1) ESP is designed to meet specified needs of the learner; (2) ESP is related in content to specific disciplines and occupations; (3) ESP focuses on the language and discourses appropriate to these disciplines and occupations. 


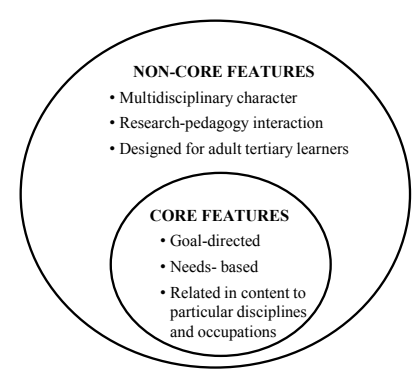

Figure 1. Features of ESP.

ESP is basically characterized by a set of core features on which ESP experts seem to agree. First and foremost, ESP is goal-directed or "end-focused" (Kerr, 1977, p. 11), the aim being to communicate effectively in specific scientific fields and professional settings. Second, ESP is a learner needs-based approach. Meeting the needs of the learners is a focus of ESP. The primacy of needs analysis (i.e. the identification of the learners' purposes) is widely recognised in the ESP sphere (e.g. Kennedy \& Bolitho, 1984; Hutchinson \& Waters, 1987; Robinson, 1991; Dudley-Evans \& St John, 1998; Huhta et al., 2013). Needs analysis is the main factor in determining course design, methodology and materials, as pointed out by Munby (1978, p. 2): “ESP courses are those where the syllabus and materials are determined [...] by the prior analysis of the communicative needs of the learners." The third core feature of ESP is related to the first one. If the aim of ESP is to use English for academic or occupational purposes, then it must be related in content to particular disciplines and occupations.

We will now turn our attention to the non-core features of ESP. First, ESP has a multidisciplinary character (Dudley-Evans \& St John, 1998, p.19; Wilkinson, 2008, p. 61) drawing from both language and learning theories and various disciplines such as psycholinguistics, sociolinguistics and sociology. As a matter of fact, the influence of different linguistic theories on ESP has generated new movements in ESP throughout its history (see below). Second, ESP is characterized by a research-pedagogy interaction, although the focus is on teaching. The research into language, genres and contexts of use has pedagogical purposes and ESP teaching/learning is directed by the research carried out within a specific field. Third, ESP courses are largely designed for adult tertiary students in non-English speaking countries.

Categorizations of the ESP area abound in the ESP literature. The main classifications for the different offshoots of ESP are expressed in figure 2: 


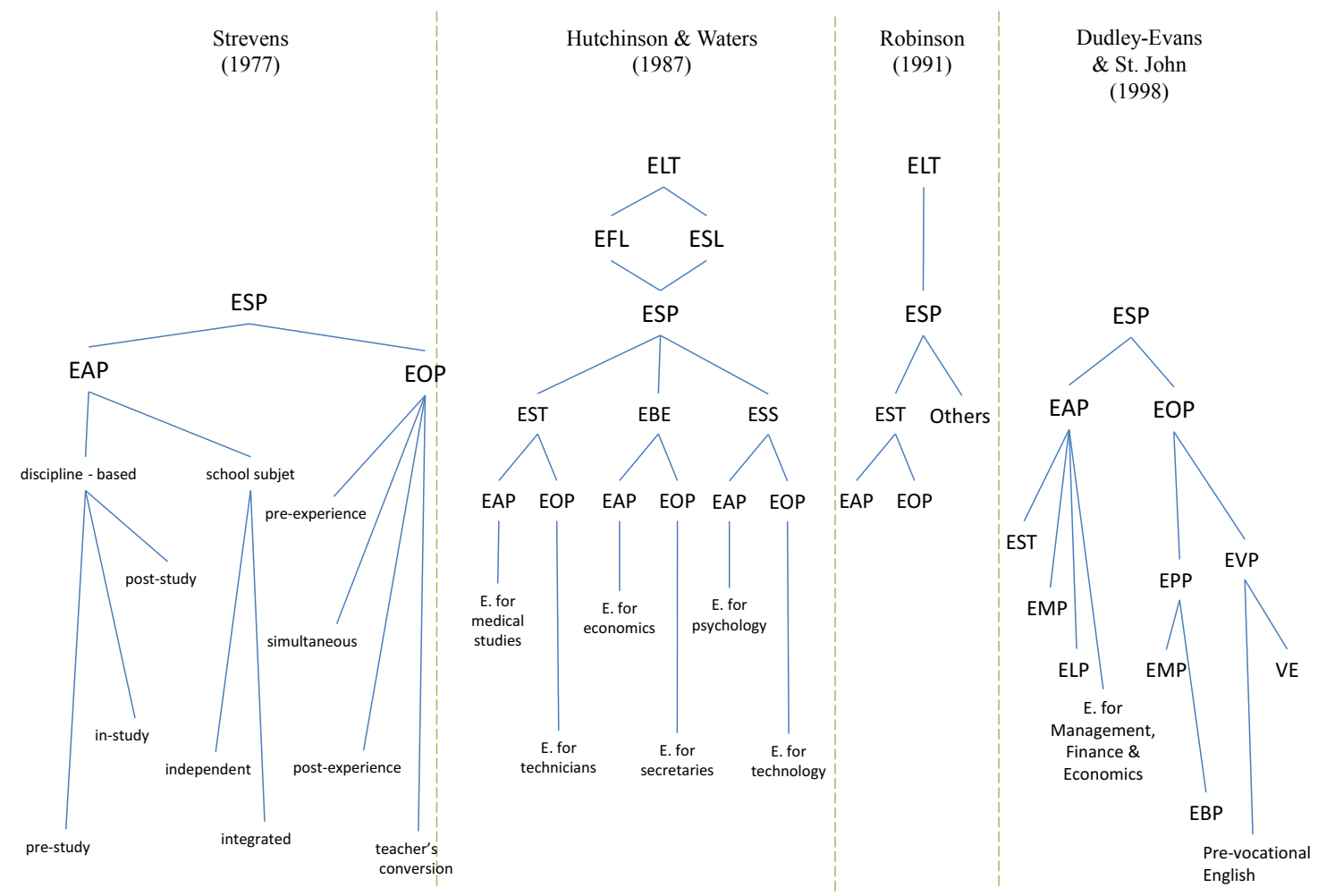

Figure 2. Classifications of ESP.

Despite the array of labels for ESP, there is a traditional division into two broad subfields: English for Academic Purposes (henceforth EAP), involving academic study needs, and English for Occupational Purposes (hence EOP), involving work-related needs. Cutting across this broad division Strevens (1977) suggests a further division of occupational and academic English courses according to when they take place. Thus EOP can be taught before or after the learner has worked in a specific field (pre-experience or post-experience), or when the learner is working (simultaneous). EAP is in turn divided into discipline-based English in higher education and school-subject English. The former type of EAP may be taught when the student is specializing (in-study) or intends to specialize (pre-study) in a particular subject. School-subject EAP can be taught as a separate subject (independent) or can be the medium of instruction in other subjects (integrated). In a later version (1988, p. 92) Strevens draws a basic distinction between EST (English for Science and Technology) and other areas of ESP, and suggests a further type of EOP, teacher's conversion, i.e. ESP courses taken by practicing teachers.

Hutchinson and Waters (1987, p.17) see ESP as a branch of English as a second/foreign language, which are the main strands of ELT. Three categories 
of ESP are identified according to the professional area: English for Science and Technology (EST), English for Business and Economy (EBE) and English for the Social Sciences (ESS). Each course may be divided into two main types according to whether English is required for academic study or for work/training: EAP and EOP.

In much the same way, Robinson (1991, pp. 3-6) considers ESP as an area of ELT divided into EAP and EOP. Cutting across these is EST, which can refer to the English needed for both study and work purposes. Her ESP "family tree" differs from Strevens' in that the English needed in a particular discipline can also be taught after the student has specialized (post-study).

Dudley-Evans and St John (1998, p. 6) classify ESP by professional area. EAP covers the areas of Science and Technology (EST, the main branch), Medicine and Health Sciences (EMP), Law and Administration (ELP), and Business and Economics. EOP covers two areas: (1) English for Professional Purposes (EPP), which has two branches: Medicine (EMP) and Business (EBP); and (2) English for Vocational Purposes (EVP), which has two subsections: pre-vocational English, which is concerned with finding a job and interview skills; and Vocational English (VE), which is concerned with the language of specific occupations. Most interestingly, these authors place ESP at one end of the ELT continuum, the other end being General English.

The ESP landscape is complicated by three factors: (i) further subdivisions within the broad ESP area such as the distinction between English for General Academic Purposes (EGAP) and English for Specific Academic Purposes (ESAP) drawn by Dudley-Evans and St John (1998, p.41); (ii) combinations of EOP and EAP elements such as EAMP (for health science students), EABP (for business students), and EALP (for law students); and (iii) new ESP specializations such as ESCP (English for Sociocultural Purposes) to meet the immigrant learners' survival needs (e.g. Master, 2000; De Silva \& Hood, 2009).

\section{A historical overview of ESP}

The stages in ESP development are determined by changes in the linguistic approach to ESP and changes in ESP teaching and learning. Four stages can be distinguished:

1. Mid-1960s - early 1970 s 
Interest in "special-purpose language teaching" (McDonough, 1984, p.1) began in the mid-1960s. ESP emerged as an activity within ELT from a huge demand for English for study or work purposes. Its appearance resulted from several factors, namely the scientific, technological and economic growth, the increased use of English as the international language of science, technology and business and the economic power of the USA.

The view of language as communication led to new trends in linguistic description which influenced ESP. The first trend is concerned with the notion of language variation and the development of register analysis (Halliday et al., 1964). Language variation involves the existence of varieties of language related to specific contexts of use. Operating on the principle that language varies according to the user (registers), analysts identified the grammatical and lexical features of these registers, which ESP courses adopted as their syllabus. The approach was thus sentence-based and form-focused. Most research was carried out into EST registers (Huddleston et al., 1968; Swales, 1971). Thus early ESP courses concentrated on the grammar and vocabulary of scientific English (e.g. Close, 1965; Herbert, 1965, Ewer and Latorre, 1969, Swales, 1971; DudleyEvans, 1977), as shown by Ewer and Latorre (1969, p.122): "There is a basic language of scientific English, made up of sentence patterns, structural words and non-structural words common to all the sciences. It is to this essential framework that the large specialized vocabularies of each discipline are added."

Other varieties were discussed such as medical English (e.g. Allwright \& Allwright, 1977; Candlin et al., 1978) and business English (e.g. Eckerley and Knufmann, 1973). The publication of Bellcrest File (1972), a video-based business English coursebook marked the beginning of a new movement in EBP which paid attention to the four skills and would be later represented by the Longman Business English Skills series (1987 onwards). In contrast, little work was done on ESP teaching and learning (e.g. Sturtridge, 1977; Wheeler, 1977).

A quantitative approach to ESP followed and frequency studies (e.g. Barber, 1962) were carried out to select the inventory of lexical items to be taught. Ewer and Latorre (1967) set out the foundations of ESP in terms of selection and frequency. They established the relative frequency and range of items under three headings (sentence patterns, non-structural lexis and function words and phrases) on the basis of a large corpus of texts from ten areas of science.

The main contribution of the early days of ESP is that the learner aims and needs were for the first time taken into consideration in English teaching, and 
there was an interest in designing courses tailored to the demands of particular groups of learners. On the negative side, ESP was equated with EST, it was heavily structure-based and paid insufficient attention to meaning.

\section{Mid-1970s-mid-1980s}

In the second stage of development four changes took place in the field of $\mathrm{ESP}^{4}$.

(1) The shift within the ELT field towards a more communicative view of language teaching and learning (e.g. Widdowson, 1978) influenced EST materials production. Attention shifted away from the structure of forms to their meaning (notions and functions) and to the analysis of forms in context (Allen, 1978; Widdowson, 1983). Grammatical choice was considered to be dependent on purpose and use became the main criterion for the selection of ESP materials (Widdowson, 1975). The grammatical syllabus was replaced by a syllabus built around rhetorical functions, as illustrated by the major EST textbook series of the time, the Focus Series, with nine volumes from 1977 to 1983, where the emphasis was on key functions in scientific and academic writing. The other was the Nucleus series edited by Bates and Dudley-Evans (Longman), which focused on the function of description and introduced semi-technical scientific vocabulary.

The major strength of the functional approach is that use, a crucial aspect of language learning, became the starting point in ESP learning. The relevance of this notion was highlighted by Widdowson (1978, p. 13): "Teaching English as a medium for science and technology must involve us in the teaching of how scientists and technologists use the system of the language to communicate, and not just what linguistic elements are most commonly used."

A criticism of the functional approach is that it came to replace a grammaticallexical inventory by an inventory of functions. In addition, it left some questions open, such as the criteria for the selection of communicative functions, the sequencing of functions in teaching materials and the overlap of functions in many statements and texts.

(2) The second change is associated with the new linguistic approach to ESP, i.e. rhetorical analysis, which influenced the structural and lexical approach. What was relevant was not so much the frequency of feature $x$ or $y$ but the reason for the choice of $x$ rather than $y$ in the text. Attention thus shifted from the sentence level to the level of text and the writer's purpose. The main concern was to identify textual patterns and specify the linguistic forms that signal these patterns. These patterns formed the syllabus of ESP courses. The work on EST done in the USA by

\footnotetext{
4 A report of ESP research and practice in this period is found in Mackay and Mountford (1978).
} 
Lackstrom, Selinker, Trimble and Todd Trimble (Lackstrom, Selinker \& Trimble, 1970; Selinker, Lakstrom \& Trimble, 1973; Selinker, Trimble \& Vroman, 1974; Selinker, Todd Trimble \& Trimble, 1976, 1978; Trimble, 1985) is representative of this new trend in ESP. Trimble led this group in the development of the "grammatical-rhetorical" approach, which fundamentally assumed that in researching scientific and technical language use, it is not sufficient to identify grammatical forms in isolated sentences; rather, it is important to identify the relationships between such grammatical forms and their rhetorical function in the discourse. Discourse is here defined as a collection of connected sentences and paragraphs that together make up a coherent, cohesive text. Rhetoric is the process a writer uses to produce a desired piece of text. This process is basically one of choosing and organizing information for a specific set of purposes and a specific set of readers. In line with this, an EST text is concerned only with the presentation of facts, hypotheses, and similar types of information (Trimble, 1985: 10).

This new trend in ESP incorporated the textual dimension and the context to ESP analysis. As a matter of fact, ESP activity has since then been linked to a view of text. The weaknesses of register analysis are that it was only applied to scientific communication and it was restricted to the identification of rhetorical functions (e.g. description, classification) and their linguistic realizations.

(3) The third change was connected with ESP course design. Needs analysis, i.e. the analysis of the linguistic features of the target situation (e.g. Chambers, 1980, p. 29), became the starting point for ESP syllabus design. Needs were thus specified in terms of goals because the emphasis was on the product rather than on the process of learning. In Hutchinson and Water's (1987, p. 8) words, "tell me what you need English for and I will tell you the English you need." A major landmark in the development of ESP was the Communicative Needs Processor (CNP) set out by Munby (1978), a procedure to establish a profile of target situation needs in the form of questions about key communication variables (topic, participants, media). ${ }^{4}$

(4) The last change was related to ESP teaching. The rise of a skills and strategies approach is related to the development of needs analysis, which identified the most important skills in a specific situation. The skills approach, proposed by Candlin et al. (1978) and exemplified by books like Skills for Learning (1980), switched the focus from the teaching of language (grammar and vocabulary) to the teaching of the basic skills. Skills analysis was carried out on three levels: 1) mode is concerned with the 'study situation' (e.g. lecture, private study); 2) skills or macro-skills (e.g. reading comprehension); and 3) sub-skills or microskills (e.g. skimming, perception of individual sounds). The skills approach highlighted the instrumental facet of ESP learning which had so far been identified with key linguistic features.

While the previous stages concentrated on language use, this stage was an attempt to consider the thinking processes underlying language use. The idea 
behind the strategies approach is that there are interpretive strategies that enable learners to perform in English. This approach shed light on the perceptual and psychological factors underlying language learning and generated a journal, The ESP-ecialist, and teaching materials such as the Reading and Thinking in English series (1980) and Skills for Learning (Nelson and the University of Malaya Press, 1970).

\section{Mid-1980s-1990s}

The third phase of development of ESP was characterized by two new directions: (i) a linguistic direction, namely discourse and genre analysis, and (ii) a pedagogical direction based on the learning-centered approach put forward by Hutchinson and Waters (1987), which was in consonance with new developments in educational psychology that emphasized the importance of the learners and their attitudes to learning. ${ }^{5}$

Discourse analysis involves both text analysis and a specific analytical method. Genre analysis is part of discourse analysis. It is concerned with the study of the forms of discourse that particular discourse communities ${ }^{6}$ engage in, their communicative conventions and purposes, the role texts play in particular contexts, their genre products, and the differences between the discourses within and of various discourse communities. Textual findings are thus related to features of the discourse community within which the genre is produced, and this is one of the main advantages of genre analysis as compared with discourse analysis (Dudley-Evans \& St John, 1998, pp. 91-92).

Swales took the lead in the field of genre analysis. His pioneering work on the introduction to academic articles from a range of disciplines ${ }^{7}$ (Swales, 1981, 1990) was followed by further investigations (Swales, 1986, 1988, 1990; Crookes, 1986; Dudley-Evans, 1987, 1989; Hopkins \& Dudley-Evans, 1988; Salager-Meyer et al., 1989; Swales \& Feak, 1994; Bhatia, 1993; Eggins \& Martin, 1997).

5 The C.N.P consisted of the following categories: purposive domain, setting, interaction, instrumentality, dialect, target level, communicative event, communicative key.

6 Johns and Dudley-Evans (1993) and Khuwaileh (1993) present an overview of the state of ESP in the 1990s.

7 According to Swales (1990, pp. 24-27), a discourse community has an agreed set of common public goals and mechanisms of intercommunication used to provide information and feedback; it uses one or more genres to achieve its goals; it has additionally acquired specific lexis and has a threshold level of members with content and discoursal expertise. 
Discourse analysis has significantly enriched research in all areas of ESP by revealing the distinguishing features of specific texts across disciplines (e.g. academic articles, sales promotion letters, sales negotiations, laboratory demonstrations). In addition, it has been useful in helping SS to cope with writing tasks (Bhatia, 1993).

A learning-centered approach (i.e. how people learn) was postulated by Hutchinson and Waters (1987, p. 2) rather than the language-centered approach (i.e. what people learn) which had prevailed since the 1960s. While in the previous stages ESP was concerned with language use, the new approach was concerned with language learning ${ }^{8}$, and the methodology put the emphasis on pair/group work and problem-solving. The focus shifted from an end-product definition of needs (target needs, i.e. what the learner needs to do in the target situation) to a process-oriented definition of needs (learning needs, i.e. what the learner needs to do in order to learn). Hutchinson and Waters (1987, pp. 62-63) set out the framework for analyzing learning needs. ${ }^{9}$

The learning-centered approach influenced course design. Hutchinson and Waters (1987, pp. 72-73) contrasted the learning-centered approach to course design with the language-centered approach and the skills-centered approach:

a) A language-centered approach says: This is the nature of the target situation performance and that will determine the ESP course.

b) A skills-centered approach says: We must discover what processes enable someone to perform. Those processes will determine the ESP course.

c) A learning-centered approach says: We must discover how someone acquires the competence to perform. Learning is totally determined by the learner.

Further publications increased the body of research into ESP (e.g. Chamberlain \& Baumgardner, 1987; Dudley-Evans, 1988; Piqué \& Viera, 1997). A considerable proportion of books and papers treated EAP (e.g. Jordan, 1997), especially academic writing (e.g. Swales \& Feak, 1994; Dudley-Evans, 1995).

8 Swales' model (1990, p. 141) postulates a regular pattern of moves and steps in article introductions. A move is a unit related both to the writer's purpose and to the content. A step is a lower level unit that offers a detailed perspective on the options open to the writer in setting out the moves.

$9 \quad$ Hutchinson (1987, pp. 71-75) set out the basic principles of learning which provide a basis for the definition of ESP: (i) learning is development; (ii) learning is a thinking process; (iii) learning is an active process; (iv) learning a language is not just a matter of linguistic knowledge; (v) SL learners are already communicatively competent; (vi) learning is an emotional experience; and (vii) learning is not systematic; and (viii) learning needs should be considered at each stage of the learning process. 
Nevertheless, the most significant growth was that of Business English (cf. St John, 1996).

\section{2000s-present}

In the fourth stage of development genre analysis has taken new directions in ESP (e.g. Flowerdew, 2000; Bhatia, 2004, 2008; Gotti \& Giannoni, 2006; GarcésConejos, 2010; Bosio et al., 2012) and has incorporated the recent developments in genre theory (Paltridge, 2001; Hyland, 2004; Swales, 2004, 2007). One such development is the sociological consideration of the context in which texts are written (e.g. Berkenkotter et al., 1991), especially in the professional and business contexts (Bazerman, 1988; Myers, 1990; Bazerman \& Paradis, 1991). Berkenkotter and Huckin (1995, pp. 2-3) argue that genre studies have tended to 'reify' genres and see them as 'linguistic abstractions'.

Another development in genre studies has been brought about by the recognition of the influence of culture on the structure of genres (e.g. Melander, 1998, pp. 221-226). As Dudley-Evans and St John (1998, p. 66) point out, "a sensitivity to cultural issues and an understanding of our own and others' values and behaviors is important in ESP."

Two further approaches from which ESP has greatly benefited are contrastive rhetoric (Connor, 1996; Connor et al., 2008) and corpus linguistics (e.g. Biber et al., 2007). Corpus linguistics has given ESP experts access to megadatabanks of authentic spoken and written texts (e.g. Gavioli, 2005). They can compile and examine their own specialized corpora in order to determine the distribution of specific and grammatical features within and across texts, and identify similarities and differences between domain-specific genres and everyday language.

It is worth mentioning that new technologies have brought about developments in ESP pedagogy such as self-directed learning through online platforms (e.g. González-Pueyo et al., 2009; Luzón et al., 2010).

If we consider ESP work, much of it is devoted to academic and professional discourse (e.g. Alcaraz, 2000; Hyland \& Bondi, 2006; Sales, 2006; Alcaraz et al., 2007). There is an impressive amount of research into academic English (e.g. Hyland, 2006; Fløttum et al., 2006; Suomela-Salmi \& Dervin, 2009), mainly concerned with academic writing (e.g. Hyland, 2000; Bailey, 2003). This 
contrasts with the scant attention paid to academic writing and speaking at university level in western Europe (Fortanet \& Räisänen, 2008). Nonetheless, the majority of the publications on ESP are concerned with practical aspects of ESP teaching and specific EAP programmes (e.g. Orr, 2002; Bocanegra et al., 2007; Bocanegra, 2010), although a few also deal with theoretical issues (e.g. Belcher, 2004, 2009). At the same time EBP has been a very large sector for published materials (e.g. Ellis \& Johnson, 1994; the Market Leader series) and there have also been a number of applications in EST (e.g. García-Mayo, 2000), and EMP (English for Medical Purposes). Globalization has also increased the demand for ELP (English for Legal Purposes).

In the field of teaching and learning, ESP in Western Europe is divided into three blocks: EAP, EST and Business English - the main area. In addition, the growing use of English in Master and PhD theses has increased the need for EAP instruction. The position of ESP in Europe has become dependent on language policy matters. Thus, the restructuring of higher education in European countries in the light of the Bologna Declaration (1999) has brought about major changes in ESP tuition at university. ${ }^{10}$ The Bologna reform intended to harmonize European higher education and to promote plurilingualism and student mobility. One of the tools to promote language learning is the use of foreign languages as mediums of instruction. The rise of English as a medium of instruction (EMI) in European higher education since the implementation of the Bologna reforms in 2005 and the European Higher Education Area (EHEA) ${ }^{11}$ in 2010 is the result of its status of lingua franca in technology, business and research, which has led to the design of university ESP courses in a range of subject areas to meet the strong demand for specialized English. ${ }^{12}$

The use of English as a medium of instruction has given rise to a new approach, Content Language Integrated Learning (henceforth CLIL). CLIL is a dual focused educational approach which involves competence building in language knowledge and skills, whereas it is not specifically language learning and not

10 The framework for analyzing learning needs consists of a set of questions: Why are the learners taking the course? How do the learners learn? What resources are available? Who are the learners? Where will the ESP course take place? When will the ESP course take place?

11 Fortanet and Räisänen (2008) highlight the impact of the Bologna reform on the teaching and learning of ESP in western Europe.

12 The creation of the EHEA was meant to increase student employability and facilitate the access to the labour market to graduate and postgraduate students. 
specifically subject learning but is a fusion of both (Maljers et al., 2007) ${ }^{13}$ and aims to integrate content and language in the domain-specific courses.

Although in many European countries ESP training remains an adjunct (compulsory or optional) component in the study of a discipline and is taught independently using specially created ESP material, in the Netherlands and Sweden ESP instruction has been integrated within the content programme (cf. Fortanet \& Räisänen, 2008). In this context, the teaching of ESP in higher education is seen as sharing methodologies and activities with the disciplines with which it is associated, and focusing on the terminology, grammar, characteristics of discourse and genres of those disciplines (Räisänen \& Fortanet, 2008, p. 12).

There are several forms of cooperation between the content teachers and the ESP teachers in adjunct FL courses in the context of content-based learning instruction: (i) collaborative learning; (ii) team teaching, and (III) linked ESP and subject area, or learning communities (Johnson, 2000; Johns, 2009). In collaborative learning ESP teachers use the materials and tasks that students are assigned in the content courses. In team teaching both English and content teachers correct papers and share grading. In learning communities their members take the same classes. Subject matter in the shared subject areas can become a source of materials and tasks for the ESP class, and teachers can consult each other on the learners' needs. Actually, ESP engagement with subject courses has undermined the status of ESP at tertiary institutions and might be a threat to the profession of ESP teachers. There seems to be an inconsistency between the widely accepted need for ESP learning and the reduction of ESP courses in credits and the view of ESP teachers brought about by the CLIL methodology. ESP instructors are seen as support for content teachers rather than collaborators (Fortanet \& Räisänen, 2008, pp. 3, 7). Team teaching is rare, the only examples being found in the Netherlands and Sweden.

\section{Conclusion}

English has long been considered the language of communication in the academic and professional worlds. ESP appeared in the mid-1960s in response to a strong demand for specialized English for professional or occupational purposes. The ESP literature has grown ever since.

13 Cf. Doiz et al. (2013) for English-medium tuition in the tertiary level. 
ESP, traditionally divided into EAP and EOP, is a ELT movement whose main concerns are needs analysis, discourse analysis and learners' training for particular study or work purposes. ESP developments have been determined by changing approaches to linguistic analysis for ESP. In the 1970s ESP was indebted to the tradition of register analysis, which paid attention to the formal characteristics of language varieties. The focus was on the word and sentence level. The bulk of ESP work was concerned with the scientific registers. The most important teaching materials published in the early stages (the Focus and Nucleus series) highlighted the functional/notional aspects of language description which were considered in the new communicative view of language learning. In the second phase of development ESP was closely involved with rhetorical analysis. The approach to ESP was text-oriented and ESP courses were learner need-based. Skills were the core of syllabus design. From the 1980s to the end of the 20th century discourse analysis contributed to ESP by showing the common core of language and the discursive features of all academic disciplines. ESP was grounded on the work done by Swales and Bhatia in the field of genre analysis, and ESP pedagogy considered both learners and learning factors. In the last two decades ESP practice has remained largely genre-based. Genre analysis appears to be a fruitful line of investigation in the areas of academic and occupational English and will be a major inspiration for the development of ESP. It is hoped that research into other genres and subgenres, including spoken genres, will have implications for ESP pedagogy.

ESP instruction has been influenced by a number of factors:

a) Globalization and the status of English as a lingua franca in academic and business contexts have stimulated the huge growth of ESP.

b) The Bologna Process, which aimed to promote language learning and linguistic diversity, has had an impact on tertiary-sector ESP in western Europe. There has been an increasing specialization of English learning at tertiary level within the CLIL approach, ${ }^{14}$ which promotes the teaching of non-linguistic subjects in a foreign language, thus establishing a connection between language learning and content learning. Nowadays two approaches to tertiary-level ESP teaching coexist in Western Europe: (1) ESP is an adjunct course component and is taught independently; (2) ESP is integrated with disciplinary content. The problem is that ESP courses are a support of subject courses, the aim being to provide help to

14

There is a growing body of work on CLIL at university level (e.g. Marsh, 2006; Wolff \& Marsh, 2007; Wilkinson \& Zegars, 2007; Mehisto et al., 2008; Ruiz de Zarobe \& Jiménez, 2009; Fernández, 2009; Coyle et al., 2010; Maljers et al., 2007; Dalton-Puffer, 2011; Dafouz \& Guerrini, 2009; Smit \& Dafouz, 2012; Fortanet, 2013). 
learn content. It is hoped that ESP will find the way to fit in the CLIL pedagogy without renouncing its essence.

\section{About the authors}

Isabel Negro Alousque is an assistant lecturer at the English Department at the Complutense University in Madrid. She has collaborated in writing two books on business English and has published several articles in international journals. Her research interests are English for Specific Purposes, cognitive semantics, lexicology and translation.

\section{Article history}

Paper received: $18^{\text {th }}$ June 2015

Paper received in revised form and accepted for publication: $29^{\text {th }}$ March 2016

\section{References}

Alcaraz-Varó, E. (2000). El inglés profesional y académico. Madrid: Alianza Editorial.

Alcaraz, E., Mateo, J. \& Yus, F. (Eds.) (2007). Las lenguas profesionales y académicas. Barcelona: Ariel.

Allen, J. P. B. (1978). Teaching the communicative use of English. In R. Mackay \& A. Mountford (Eds.), English for Specific Purposes (pp. 56-77). London: Longman.

Allen, J. P. B. \& Widdowson, H.G. (1974). English in Focus. Oxford: Oxford University Press.

Allwright, J. \& Allwright, M. (1977). An approach to the teaching of medical English. In S. Holden (Ed.), English for Specific Purposes (pp. 58-62). Oxford: Modern English Publications.

Anthony, L. (1997). English for Specific Purposes: What does it mean? Why is it different? ONCUE, 4 (3), 9-10.

Bailey, S. (2003). Academic Writing. London: Routledge.

Barber, C. L. (1962). Some measurable characteristics of modern scientific prose. In J.M. Swales (Ed.) (1988), Episodes in ESP: A Source and Reference Book on the Development of English for Science and Technology (pp. 3-14). New York: Prentice-Hall. 
Bates, M. \& Dudley-Evans, T. (1976). Nucleus. English for Science and Technology. London: Longman.

Bazerman, C. (1988). Shaping Written Knowledge. Madison, Wisconsin: University of Wisconsin Press.

Belcher, D. (2004). Trends in teaching English for Specific Purposes. Annual Review of Applied Linguistics, 24, 165-186.

Belcher, D. (Ed.) (2009). English for Specific Purposes: Theory and Practice. Ann Arbor: University of Michigan Press.

Berkenkotter, C., Huckin, T.N. \& Ackerman, J. (1991). Social contexts and socially constructed texts: the initiation of a graduate student into a writing research community. In C. Bazerman \& J. Paradis (Eds.), Textual Dynamics of the Professions. Historical and Contemporary Studies of Writing in Academic and Other Professional communities (pp. 191215). Madison, Wisconsin: University of Wisconsin Press.

Berkenkotter, C. \& Huckin, T.N. (1995). Genre Knowledge in Disciplinary Communication: Cognition, Culture, Power. Hillsdale, N.J.: L. Erlbaum Associates.

Bhatia, V. K. (1993). Analysing Genre: Language Use in Professional Settings. London: Longman.

Bhatia, V. K. (2004). Worlds of Written Discourse: A Genre-Based View. London: Continuum.

Bhatia, V. K. (2008). Genre analysis, ESP and professional practice. English for Specific Purposes, $27(2), 161-174$.

Biber, D., Connor, U. \& Upton, T.A. (2007). Discourse on the Move, Using Corpus Analysis to Describe Discourse Structure. Amsterdam/Philadelphia: John Benjamins.

Bocanegra, A., Lario de Oñate, M.C. \& López, E. (Eds.) (2007). English for Specific Purposes: Studies for Classroom Development and Implementation. Cádiz: Universidad de Cádiz.

Bocanegra, A. (2010). Evaluating and designing materials for the ESP classroom. In M.F. Ruiz, J.C: Palmer \& I. Fortanet (Eds.), English for Professional and Academic Purposes (pp. 141-166). Amsterdam/New York: Rodopi.

Bosio, I., Castel, V., Ciapuscio, G., Cubo, L. \& Muller, G. (Eds.) (2012). Discurso especializado: Estudios teóricos y aplicados. Mendoza: Sociedad Argentina de Lingüística y Editorial de la Facultad de Filosofía y Letras, Serie Volúmenes temáticos de la Sociedad Argentina de Lingüística.

Candlin, C. N., Kirkwood, J.M. \& Moore, H. M. (1978). Study skills in English: theoretical issues and practical problems. In R. Mackay \& A. Mountford (Eds.), English for Specific Purposes (pp. 190-219). London: Longman.

Carver, D. (1983). Some propositions about ESP. The ESP Journal, 2, 131-137.

Chamberlain, D. \& Baumgardner, R.J. (Eds.) (1987). ESP in the Classroom. Practice and Evaluation. London: Macmillan.

Chambers, F. (1980). A re-evaluation of needs analysis. ESP Journal, 1 (1), 25-33. 
Close, R. A. (1965). The English We Use for Science. London: Longman.

Connor, U. (1996). Contrastive Rhetoric: Cross-cultural Aspects of Second Language Writing. Cambridge: Cambridge University Press.

Connor, U., Nagelhout, E. \& Rozycki, W. (Eds.) (2008). Contrastive Rhetoric: Reaching to Intercultural Rhetoric. Amsterdam/Philadelphia: John Benjamins.

Coyle, D., Hood, P. \& Marsh, D. (2010). Content and Language Integrated Learning. Cambridge: Cambridge University Press.

Crookes, G. (1986). Task Classification: A Cross-disciplinary Review. Center for Second Language Classroom Research, Social Science Research Institute, University of Hawaii at Manoa.

Dafouz, E. \& Guerrini, M.C. (Eds.) (2009). CLIL across Educational Levels. Experiences from Primary, Secondary and Tertiary Contexts. Madrid: Richmond Santillana.

Dalton-Puffer, C. (2011). CLIL: From practice to principles? Annual Review of Applied Linguistics, 31, 182-204.

De Silva, H. \& Hood, S. (2009). English for community membership. Planning for factual and potential needs. In D. Belcher (Ed.), English for Specific Purposes: Theory and Practice (pp. 244-263). Ann Arbor: University of Michigan Press.

Doiz, A., Lasagabaster, D. \& Sierra, J.M. (Eds.) (2013). English-medium Instruction at University. Global Challenges. Bristol: Multilingual Matters.

Dudley-Evans, T. (1977). Planning a course for science and engineering students. In S. Holden (Ed.), English for Specific Purposes (pp. 38-40). Oxford: Modern English Publications.

Dudley-Evans, T. (1988). Recent developments in ESP: The trend to greater specialization. In M. L. Tickoo (Ed.), ESP: State of the Art (pp. 27-32). Singapore: SEAMEO Regional English Language Centre.

Dudley-Evans, T. (1995). Common core and specific approach to the teaching of academic writing. In D. Belcher \& G. Braine (Eds.), Academic Writing in a Second Language (pp. 293312). Norwood, N.J.: Ablex.

Dudley-Evans, T. \& St John, M.J. (1998). Developments in English for Specific Purposes: A Multidisciplinary Approach. Cambridge University Press.

Eckerley, C. \& Knufmann, W. (1973). English for Business. Oxford: Oxford University Press.

Eggins, S. \& Martin, J.R. (1997). Genres and registers of discourse. In T. A. van Dijk (Ed.), Discourse as Structure and Process (pp. 230-256). London: Sage.

Ellis, M. \& Johnson, C. (1994). Teaching Business English. Oxford: Oxford University Press.

English for Business: Bellcrest File. A. Drummond. 1972. Oxford: Oxford University Press.

Ewer, J. \& Latorre, G. (1967) Preparing an English Course for Students of Science. English Language Teaching, 21, 221-229.

Ewer, J. \& Latorre, G. (1969). A Course in Basic Scientific English. London: Longman. 
Fernández, D. J. (2009). CLIL at the university level: Relating language teaching with and through content teaching. Latin American Journal of Content and Language Integrated Learning, 2 (2), $10-26$.

Fløttum, K., Dahl, T. \& Kinn, T. (2006). Academic Voices across Languages and Disciplines. Amsterdam/Philadelphia: John Benjamins.

Flowerdew, L. (2000). Using a genre-based framework to teach organizational structure in academic writing. ELT Journal, 54 (4), 369-78.

Focus series. 1977-1983. Oxford: Oxford University Press.

Fortanet, I. (2013). CLIL in Higher Education. Towards a Multilingual Language Policy. Bristol: Multilingual Matters.

Fortanet, I. \& Räisänen, C.A. (2008). The state of ESP teaching and learning in western European higher education after Bologna. In I. Fortanet \& C.A. Räisänen (Eds.), ESP in European Higher Education. Integrating Language and Content (pp. 11-51). Amsterdam/Philadelphia: John Benjamins.

Fortanet, I. \& Räisänen, C.A. (Eds.) (2008). ESP in European Higher Education. Integrating Language and Content. Amsterdam/Philadelphia: John Benjamins.

Garcés-Conejos, P. (2010). Who 'we' are: the construction of American corporate identity in the Corporate Values Statement genre. In M.F. Ruiz, J.C. Palmer \& I. Fortanet (Eds.), English for Professional and Academic Purposes (pp. 121-137). Amsterdam/New York: Rodopi.

García-Mayo, P. (2000). English for Specific Purposes: Discourse Analysis and Course Design. Servicio Editorial de la Universidad del País Vasco.

Gavioli, L. (2005). Exploring Corpora for ESP Learning. Amsterdam/ Philadelphia: John Benjamins.

González-Pueyo, I., Foz, C., Siso, M. \& Luzón, M.J. (Eds.) (2009). Teaching Academic and Professional English Online. Bern: Peter Lang.

Gotti, M. \& Giannoni, D.S. (Eds.) (2006). New Trends in Specialized Discourse Analysis. Bern: Peter Lang.

Halliday, M. A. K., McIntosh, A. \& Strevens, P. (1964). The Linguistic Sciences and Language Teaching. London: Longman.

Herbert, A. J. (1965). The Structure of Technical English. London: Longman.

Hopkins, A. \& Dudley-Evans, T. (1988). A genre-based investigation of the discussion sections in articles and dissertations. English for Specific Purposes, 7 (2), 113-121.

Huddleston, R. D., Hudson, R.A., Winter, E.O. \& Henrici, A. (1968). Sentence and Clause in Scientific English, mimeo. London: Communication Research Centre, Department of General Linguistics, University College.

Huhta, M. et al. (2013). Needs Analysis for Language Course Design: A Holistic Approach to ESP. Cambridge University Press. 
Hutchinson, T. (1987). Making materials work in the ESP classroom. In D. Chamberlain \& R. J. Baumgardner (Eds.), ESP in the Classroom. Practice and Evaluation (pp. 71-75). London: Macmillan.

Hutchinson, T. \& Waters, A. (1987). English for Specific Purposes. Cambridge University Press.

Hyland, K. (2000). Disciplinary Discourses: Social Interactions in Academic Writing. London: Longman.

Hyland, K. (2004). Genre and Second Language Writing. Ann Arbor: University of Michigan Press.

Hyland, K. (2006). English for Academic Purposes. London: Routledge.

Hyland, K. \& Bondi, M. (Eds.) (2006). Academic Discourse across Disciplines. Bern/New York: Peter Lang.

Johns, A. (2009). Tertiary undergraduate EAP: Problems and possibilities. In D. Belcher (Ed.), English for Specific Purposes: Theory and Practice (pp. 41-59). Ann Arbor: University of Michigan Press.

Johns, A. M. \& Dudley-Evans, T. (1993). English for specific purposes: International in scope, specific in purpose. In S. Silberstein (Ed.), State of the Art TESOL Essays: Celebrating 25 Years of the Discipline (pp. 115-132). Alexandria: TESOL.

Johnson, K. A. (2000). Communication skills for international pharmacy students. In P. Master (Ed.), Responses to English for Specific Purposes (pp. 138-141). Washington, D.C.: Bureau of Educational and Cultural Affairs.

Jordan, R. R. (1997). English for Academic Purposes: A Guide and Resource Book for Teachers. Cambridge: Cambridge University Press.

Kennedy, C. \& Bolitho, R. (1984). English for Specific Purposes. London: Macmillan.

Kerr, L. (1977). English for Special Purposes. In S. Holden (Ed.), English for Specific Purposes (pp. 11-12). Oxford: Modern English Publications.

Khuwaileh, A. (1993). ESP after 30 years. An overview of the position of ESP in the 1990s. Unesco ALSED-LSP Newsletter, 15 (1), 23-31.

Lackstrom, J., Selinker, L. \& Trimble, L. (1970). Grammar and technical English. In R.C. Lugton (Ed.), English as a Second Language: Current Issues. Center for Curriculum Development, Chilton. Reprinted in English Teaching Forum, 1972, pp. 3-14.

Longman Business English Skills. 1987. London: Longman.

Luzón, M. J., Ruiz-Madrid, M.N. \& Villanueva, M.L. (2010). Digital Genres, New Literacies and Autonomy in Language Learning. Newcastle upon Tyne, UK: Cambridge Scholars Publishing.

Mackay, R. \& Mountford, A. (Eds.) (1978). English for Specific Purposes. London: Longman.

Maljers, A., Marsh, D. \& Wolff, D. (Eds) (2007). Windows on CLIL: Content and Language Integrated Learning in the European Spotlight. Berlin: Mouton de Gruyter.

Market Leader. Pearson Longman. 
Marsh, D. (2006). English as a medium of instruction in the new global linguistic landscape. UniCOM: 29-38.

Master, P. (Ed.) (2000). Responses to English for Specific Purposes. Washington, D.C.: Bureau of Educational and Cultural Affairs.

McDonough, J. (1984). ESP in Perspective: A Practical Guide. London: Collins ELT.

Melander, B. (1998). Culture or genre Issues in the interpretation of cross-cultural differences in scientific articles. In I. Fortanet, S. Posteguillo, J. C. Palmer \& J. F. Coll (Eds.), Genre Studies in English for Academic Purposes (pp. 221-26). Castellón: Publicacions de la Universitat Jaume I.

Myers, G. (1990). Writing Biology. Texts in the Social Construction of Scientific Knowledge. Madison, Wisconsin: University of Wisconsin Press.

Mehisto, P, Marsh, D. \& Frigols, M.J. (2008). Uncovering CLIL. Content and Language Integrated Learning in Bilingual and Multilingual Education. London: Macmillan.

Moore, J. (1980). Reading and Thinking in English. Oxford: Oxford University Press.

Munby. J. (1978). Communicative Syllabus Design. Cambridge; Cambridge University Press.

Nucleus series. Eds. M. Bates \& J. Dudley-Evans. 1976. London: Longman.

Orr, T. (Ed.) (2002). English for Specific Purposes. Alexandria: TESOL.

Paltridge, B. (2001). Genre and the Language Learning Classroom. Ann Arbor: University of Michigan Press.

Piqué, J. \& Viera, D.J. (Eds.) (1997). Applied Languages: Theory and Practice in ESP. València: Universitat de València.

Robinson, P. (1991). ESP Today: A Practitioner's Guide. NewYork/London: Prentice Hall.

Ruiz, M. F., Palmer, J.C. \& Fortanet, I. (2010). Current trends in English for Professional and Academic Purposes. In M.F. Ruiz, J.C. Palmer \& I. Fortanet (Eds.), English for Professional and Academic Purposes (pp. 1-10). Amsterdam/New York: Rodopi.

Ruiz, M.F., Palmer, J.C. \& Fortanet, I. (Eds.) (2010). English for Professional and Academic Purposes. Amsterdam/New York: Rodopi.

Ruiz de Zarobe, Y. \& Jiménez, R. (2009). Content and Language Integrated Learning: Evidence from Research in Europe. Clevedon: Multilingual Matters.

Ruiz de Zarobe, Y., Sierra, J.M. \& Gallardo del Puerto, F. (Eds.) (2011). Content and Foreign Language Integrated Learning. Contributions to Multilingualism in European Contexts. Bern: Peter Lang.

Salager-Meyer, F., Defives, G., Jensen, C. \& de Filipis, M. (1989). Principal component analysis and medical English discourse: An investigation into genre-analysis. System, 17 (1), 21-34.

Sales, H. E. (2006). Professional Communication in Engineering. Basingtoke, New York: Palgrave Macmillan. 
Skills for Learning (Foundation, Progression, Development, Reading Projects: Science). 1980. Nelson and the University of Malaya Press.

Selinker, L., Lackstrom, J. \& Trimble, L. (1973). Technical rhetorical principles and grammatical choice. TESOL Quarterly, 7 (2), 127-136.

Selinker, L., Trimble, L. \& Vroman, R. (1974). Presupposition and technical rhetoric. English Language Teaching Journal, 29 (1), 59-65.

Selinker, L., Todd Trimble, M. \& Trimble, L. (1976). Presuppositional rhetorical information in EST discourse. TESOL Quarterly, 10 (3), 281 - 290.

Selinker, L, Todd Trimble, M. \& Trimble, L. (1978). Rhetorical function shifts in EST discourse. TESOL Quarterly, 12 (3), 311-320.

St John, M. J. (1996). Business is booming: BE in the 1990s. English for Specific Purposes, 15, 318.

Smit, U. \& Dafouz, E. (2012). Integrating Content and Language in Higher Education. AlLA Review, $25,1-12$.

Strevens, P. (1977). Special purpose language learning: A perspective. Language Teaching and Linguistic Abstracts, 10, 145-163.

Strevens, P. (1988). ESP after twenty years: A re-appraisal. In M.L.Tickoo (Ed.), ESP: State of the Art (pp. 1-13). Singapore: SEAMEO Regional English Language Centre.

Sturtridge, G. (1977). Using simulation in teaching English for Specific Purposes. In S. Holden (Ed.), English for Specific Purposes (pp. 32-34). Oxford: Modern English Publications.

Suomela-Salmi, E. \& Dervin, F. (Eds.). (2009). Cross-cultural and Cross-Linguistic Perspectives on Academic Discourse. Amsterdam/Philadelphia: John Benjamins.

Swales, J. M. (1971). Writing Scientific English. London: Nelson.

Swales, J. M. (1981). Aspects of Article Introductions. Aston ESP Research Reports. Birmingham: Language Studies Unit, University of Aston.

Swales, J. M. (1988). A genre-based approach to language across the curriculum. In M.L. Tickoo (Ed.), ESP: State of the Art (pp. 10-22). Singapore: SEAMEO Regional English Language Centre.

Swales, J. M. (1988). Discourse communities, genres and English as an international language. World Englishes, 7 (2), 211-220.

Swales, J. M. (1990). Genre Analysis. Cambridge: Cambridge University Press.

Swales, J. M. (2004). Research Genres: Exploration and Applications. Cambridge: Cambridge University Press.

Swales, J. M. (2007). Genre Analysis. English in Academic and Research Settings. Cambridge: Cambridge University Press.

Swales, J. M. \& Feak, C.B. (1994). Academic Writing for Graduate Students: Essential Tasks and Skills. A Course for Non-Native Speakers of English. Second edition. Ann Arbor, M.I: University of Michigan Press. 
Trimble, L. (1985). English for Science and Technology: A Discourse Approach. Cambridge: Cambridge University Press.

Wheeler, M. (1977). The role of games, simulations and role-playing exercises in language training for specific purposes. In S. Holden (Ed.), English for Specific Purposes (pp. 34-35). Oxford: Modern English Publications.

Widdowson, H. G. (1975). EST in theory and practice. E.T.I.C. Occasional Paper 1975. Oxford: The British Council.

Widdowson, H. G. (1978). Teaching Language as Communication. Oxford: Oxford University Press.

Widdowson, H. G. (1983). Learning Purpose and Language Use. Oxford: Oxford University Press.

Wilkinson. R. (2008). Locating the ESP space in problem-based learning. In I. Fortanet \& C.A. Räisänen (Eds.), ESP in European Higher Education. Integrating Language and Content (pp. 5573). Amsterdam/Philadelphia: John Benjamins.

Wilkinson, R. \& Zegars, V. (Eds.) (2007). Researching Content and Language Integration in Higher Education. Maastricht: Maastricht University Language Centre.

Wolff, D. \& Marsh, D. (2007). Diverse Contexts - Converging Goals. Content and Language Integrated Learning in Europe. Vol. 4. Frankfurt: Peter Lang. 